\title{
Evaluation and Projection of Airport Landing Movement Areas based on Statistical Analyses, ICAO 2013 Manuals and KM 44, 2002 Regulation
}

\author{
Ari Sandhyavitri 1,*, Fiqri Fansyuri ${ }^{1}$ \\ ${ }^{1}$ Engineering Faculty, University of Riau, Kampus Bina Widya Jl. HR Soebrantas KM 12,5 Pekanbaru, 28293, Indonesia \\ *Corresponding Author: ari.sandhyavitri@lecture.unri.ac.id
}

\section{Article history}

Received: 08.07.2020

Revised: 16.09.2020

Accepted: 20.09.2020

DOI:10.31629/jit.v1i2.3167

\begin{abstract}
This article demonstrated how to calculate an airport landing movement in systematic five main stages encompassing; (i) data collection (including passengers data, aircraft movements, population, GDP, per capita income, cargos movement, temperatures, ground elevation, slope surface, wind speed, and aircraft characteristics), (ii) forecasting the future traffic demands, (iii) calculating aerodrome reference field length (ARFL), (iv) define aerodrome reference code (ARF), and (v) calculate runway dimensions, taxiways, and apron areas. This article has selected Hang Nadim International Airport (HIA) as a case study. It was identified that the aircraft movements in this airport have increased by an average of $7.30 \%$ every year in the periods of 2007 to 2016. This Airport has an existing apron with a capacity of 13 aircraft, while the apron currently has to accommodate 19 aircraft. Therefore, to anticipate future demand. This research evaluated and forecasted the requirements standard for the airport landing movement areas in 2026. Based on the International Civil Aviation Organization (ICAO) 2013 manuals and KM 44, 2002 regulation concerning the National Airport Regulation. This article recommended that the existing runway and taxiways would be adequate to facilitate future aircraft movements up to 2026 . However, the apron requires to be expanded to $1,600 \mathrm{~m} \times 150 \mathrm{~m}$ (which a capacity of 31 aircraft) for accommodating the apron requirements standard in 2026 .
\end{abstract}

Keywords: airport, landing movements, runway, taxiways, apron, ICAO

\section{Introduction}

It was acknowledged that the constant growth in the air traffic movements in the airport in Indonesia over the past decade has increased the requirement for the development of the airport facilities and infrastructures [1]. It was identified that there were 7 airports which accounted for the highest cargo loads in Indonesia such as; Soekarno-Hatta International Airport, Sultan Hasanuddin International Airport, Kuala Namu
International Airport, Hang Nadim International Airport, Juanda International Airport, Sentani Airport, and Sultan Aji Muhammad Sulaiman Airport [1]. In fact, from 2007 to 2016 the Hang Nadim International aircraft movements increased by an average of $7.30 \%$ every year [2].

The capacity of an airport depends on the capacities of its landside and airside components in accommodating passenger movements, cargo and aircraft takeoff, and airport landing movements [3]. Based on Laplacea, et al. (2016), 
the population growth, GDP, and the fluctuation of the per capita incomes in a specific region may affect airport traffic movements [4].

An airport configuration may encompass various landing movement facilities such as runway, taxiway, and apron [5]. A runway is a rectangular area on the airport surface that is prepared to accommodate the takeoff and landing of aircraft. Taxiways are defined paths on the airfield surface which are established for the taxiing of aircraft. Taxiways are also intended to provide a linkage between one part of the airfield to another one. The apron is defined as an area for facilitating the aircraft to park, to check its instrument and engine prior to takeoff $[5,6,7]$.

Hang Nadim International Airport is located in Batam City, Indonesia. In 2016, the Hang Nadim Airport has a single runway (with the existing dimensions of $4015 \mathrm{~m} \times 45 \mathrm{~m}), 2$ exit taxiways $(150 \mathrm{~m} \times 23 \mathrm{~m})$, and 2 rapid exit taxiways (300m x $23 \mathrm{~m})$. The existing apron has dimensions of 690.5 $\mathrm{m} \times 76.8 \mathrm{~m}$ and $240 \mathrm{~m} \times 150 \mathrm{~m}$ with the capacity of 13 aircraft. The largest type of operating aircraft that can be operated on this runway and apron were Boeing 737-900. It was projected that the apron of this airport may accommodate 19 aircraft in 2020 [2]. Therefore, the existing apron is in a need to be expanded.

\section{Materials and Methods}

The Hang Nadim International Airport (coordinates of $011^{\prime} 07^{\prime} 15^{\prime \prime} \mathrm{NL}$ and $04^{\circ} 06^{\prime} 50^{\prime \prime} \mathrm{EL}$ ) is located in Batam City, Kepulauan Riau Province, Indonesia. The location of this airport is $\pm 7 \mathrm{~km}$ from the downtown of Batam City (Figure 1).
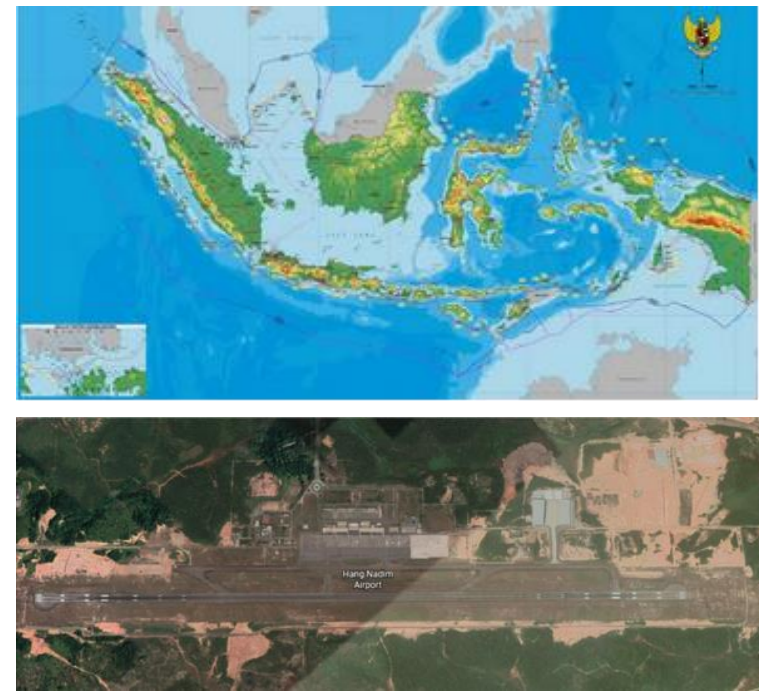

Figure 1. Hang Nadim International Airport (HIA)
This article calculated airport landing movement areas in the five main stages such as; (i) collecting data (previous passengers' data, aircraft movements, population, GDP, per capita income, cargo, temperatures, elevation, gradient, wind speed, and aircraft characteristics), (ii) forecasting the future traffic demands, (iii) calculate aerodrome reference field length (ARFL), (iv) defines aerodrome reference code (ARF), and (v) calculate runway dimensions, taxiways, and apron areas. This article has chosen a Hang Nadim International Airport (HIA) as a case study as this airport is considered one of the largest airports in Sumatra Island.

\subsection{Forecasting}

Forecasting is a process of predicting future events $[8,9]$. In the planning and decision-making processes, the prediction of future events is very crucial in making logical and rational decisions $[10,11,12]$. Therefore, forecasting is essential for making the appropriate decision in the development of airport landing movement areas. Prior to forecast airport landing movement areas (encompassing runway, taxiways, and apron) some of the following data such as passengers' data, aircraft movements, population, GDP, per capita income, and cargo should be obtained (Table 1).

Table 1. Data of Hang Nadim Int. Airport and Batam City

\begin{tabular}{|c|c|c|c|c|c|c|c|}
\hline Years & $\begin{array}{c}\text { Passenger } \\
\text { (people) }\end{array}$ & $\begin{array}{l}\text { Aircraft } \\
\text { Movem } \\
\text { ents } \\
\text { (unit) } \\
\end{array}$ & $\begin{array}{l}\text { Population } \\
\text { (people) }\end{array}$ & $\begin{array}{l}\text { GDP } \\
(\mathrm{Rp})\end{array}$ & $\begin{array}{c}\text { Percapita } \\
\text { Income } \\
\text { (Rp) }\end{array}$ & $\begin{array}{l}\text { Cargo } \\
(\mathrm{Kg})\end{array}$ & $\begin{array}{c}\text { Aircraft } \\
\text { in Peak } \\
\text { Hours } \\
\text { (unit) }\end{array}$ \\
\hline 2007 & 2.835 .662 & 27.367 & 695.739 & $47.297 .634,49$ & $34.556 .694,01$ & $22.961 .924,00$ & \\
\hline 2008 & 2.682 .181 & 25.823 & 824.964 & $52.624 .417,00$ & $36.836 .279,69$ & $24.535 .161,00$ & 9 \\
\hline 2009 & 2.910 .554 & 25.380 & 885.503 & $57.645 .949,75$ & $40.588 .181,66$ & $22.584 .306,00$ & 9 \\
\hline 2010 & 3.358 .369 & 26.089 & 954.450 & $63.640 .191,41$ & $42.379 .608,73$ & $24.693 .029,92$ & 9 \\
\hline 2011 & 3.385 .628 & 27.414 & 1.000 .661 & $74.181 .300,30$ & $44.171 .035,79$ & $25.831 .274,00$ & 10 \\
\hline 2012 & 3.918 .427 & 32.838 & 1.047 .534 & $83.751 .112,92$ & $46.266 .613,81$ & $31.296 .794,21$ & 12 \\
\hline 2013 & 4.361 .504 & 37.367 & 1.094 .623 & $96.661 .045,01$ & $49.548 .888,22$ & $32.547 .984,59$ & 14 \\
\hline 2014 & 4.944.291 & 41.554 & 1.141 .816 & $107.219 .525,72$ & $52.588 .078,64$ & $29.778 .905,00$ & 16 \\
\hline 2015 & 5.199 .019 & 43.184 & 1.188 .985 & $121.168 .686,28$ & $55.034 .822,60$ & $36.265 .619,00$ & 17 \\
\hline 2016 & 6.299 .699 & 50.290 & 1.236 .399 & $130.734 .768,94$ & $59.892 .929,89$ & $40.360 .336,00$ & 20 \\
\hline
\end{tabular}

The passengers and aircraft movement in 2026 is projected with the multi-linear and linear regression approaches. It was identified that in 10 years the number of passengers increased 300 times, aircraft movements increased by $200 \%$ as well as cargo one. The number of aircraft in peak hours have been also increased by $200 \%$.

\subsubsection{Linear Regression}

Linear regression analysis is one of the most commonly used statistical methods for modeling cross-section data $[10,11]$. In regression 
modeling, there are two kinds of variables, dependent variable (variables that are influenced or value depend on other variables) and independent variable (which is suspected to affect the dependent variable) $[10,11]$. The linear regression is formulated as follows:

$$
Y=A+B X
$$

Where:

$\mathrm{Y}=$ dependent variable

$\mathrm{A}=$ constant (the intersection of the curve to the

$\mathrm{Y}$ axis)

$\mathrm{B}=$ regression coefficient

$\mathrm{X}=$ independent variable

\subsubsection{Multi-linear regression}

Regression models with one dependent variable and more than one independent variable are called multilinear regression [10-12]. Multilinear regression is formulated as follows:

$$
Y=A+B_{1} X_{1}+B_{2} X_{2}+\cdots+B_{Z} X_{Z}
$$

Where:

$$
\begin{array}{ll}
\mathrm{Y} & =\text { dependent variable } \\
\mathrm{Xi} \ldots \mathrm{Xz} & =\text { independent variable } \\
\mathrm{A} & =\text { constant } \\
\mathrm{Bi} \ldots \mathrm{Bz} & =\text { regression coefficient }
\end{array}
$$

\subsection{Airport Configurations for Landing Movement Area}

The airport configurations for landing movement areas have an important role in the airport operation and maintenance purposes. These landing movements may encompass 2 major elements such as airport airside and airport landside areas. Both areas have been designed based on the operating characteristics of the operating aircraft. On the airside, the representative aircraft will determine the runway of taxiways [6,7,12,13,14]. The regulations applied for evaluation and design of runway and taxiways utilized the International Civil Aviation Organization (ICAO) 2013 manuals and KM 44, 2002 regulation concerning the National Airport Regulation.

\subsubsection{Runway}

A runway was designed based on the operating aircraft standards which normally utilized the longest Aeroplane Reference Field Length (ARFL). The length of the minimum runway is affected by the local conditions of the airport, such as temperature, elevation, and slope.

Where:

$$
\text { Lro }=\text { ARFL } \times \text { Ft } \times \text { Fe } \times \text { Fs }
$$

$$
\begin{array}{ll}
\text { Lro } & =\text { corrected Runway Length }(\mathrm{m}) \\
\mathrm{Ft} & =\text { temperature correction factor } \\
\mathrm{Fe} & =\text { elevation correction factor } \\
\mathrm{Fs} & =\text { slope correction factor }
\end{array}
$$

\subsubsection{Taxiway}

The major function of taxiways is to provide landside access for aircraft to travel from the runways to other areas of the airport such as from runways to the apron, runway to another runway, etc. The widths of taxiways are designed according to the type of the operated aircraft. Specifically the wingspan of the designated aircraft $[7,12,13,14]$.

\subsubsection{Apron}

An apron area will accommodate several aircraft to a board and un-board depends on the aircraft types during peak hours [7]. The planning of the apron depends on the wingspan and the length of each type of aircraft referring to ICAO Annex 14, 2013[7, 15].

\section{Results and Discussions}

The results will be discussed in 3 subsections, such as forecasting results, evaluation, and projection of the movement area, and pavement

\subsection{Forecasting results}

The forecasting result is shown in the table below:

Table 2. Forecasting result of Hang Nadim International Airport and Batam City

\begin{tabular}{cccccccc}
\hline Years & $\begin{array}{c}\text { Passenger } \\
\text { (people) }\end{array}$ & $\begin{array}{c}\text { Aircraft } \\
\text { Movements } \\
\text { (unit) }\end{array}$ & $\begin{array}{c}\text { Population } \\
\text { (people) }\end{array}$ & $\begin{array}{c}\text { GDP } \\
\text { (Rp) }\end{array}$ & $\begin{array}{c}\text { Percapita } \\
\text { Income } \\
\text { (Rp) }\end{array}$ & $\begin{array}{c}\text { Cargo } \\
\text { (Kg) }\end{array}$ & $\begin{array}{c}\text { Aircrafts in } \\
\text { Peak Hours } \\
\text { (unit) }\end{array}$ \\
\hline 2017 & 6.073 .036 & 48.663 & 1312503 & 136.400 .608 & 60.820 .273 & 39.346 .342 & 20 \\
2018 & 6.451 .855 & 51.378 & 1368036 & 146.020 .270 & 63.480 .993 & 41.212 .557 & 21 \\
2019 & 6.830 .674 & 54.093 & 1423570 & 155.639 .933 & 66.141 .713 & 43.078 .772 & 22 \\
2020 & 7.209 .493 & 56.807 & 1479103 & 165.259 .596 & 68.802 .433 & 44.944 .986 & 24 \\
2021 & 7.588 .311 & 59.522 & 1534637 & 174.879 .259 & 71.463 .153 & 46.811 .201 & 25 \\
2022 & 7.967 .130 & 62.237 & 1590171 & 184.498 .921 & 74.123 .874 & 48.677 .416 & 26 \\
2023 & 8.345 .949 & 64.952 & 1645704 & 194.118 .584 & 76.784 .594 & 50.543 .630 & 27 \\
2024 & 8.724 .767 & 67.667 & 1701238 & 203.738 .247 & 79.445 .314 & 52.409 .844 & 29 \\
2025 & 9.103 .586 & 70.382 & 1756771 & 213.357 .909 & 82.106 .034 & 54.276 .059 & 30 \\
2026 & 9.482 .405 & 73.097 & 1812305 & 222.977 .572 & 84.766 .754 & 56.142 .273 & 31
\end{tabular}


The increase in the number of passengers and aircraft movements by $150 \%$ to $200 \%$ in 10 years period (2017-2026) indicated that the existing airside facilities require to be developed. It was forecasted that in 2026 there would be more than 9.48 million passengers utilized this airport, with 73 thousand aircrafts movement, 56 tons of cargo, and 31 aircraft will park in apron per hour. Hence, at the average $150 \%$ increase in traffic demand and the number of aircraft in peak hours in 10 years (20172026). Thus, there would be necessary to calculate the future requirement of runway, taxiways, and apron to meet the increase of the traffic demand within this airport

\subsection{Movement Area}

Movement area is the part of an aerodrome to be used for the take-off, landing, and taxiing of aircraft, consisting of the maneuvering areas (runway and taxiways), and the apron $[7,15]$. The characteristics of the operating aircraft within Hang Nadim International Airport are shown in the table 3.

Table 3. The characteristics of operating aircraft at Hang Nadim International Airport

\begin{tabular}{|c|c|c|c|c|c|c|}
\hline \multirow{2}{*}{ Number } & \multirow{2}{*}{ Type of Aircraft } & \multirow{2}{*}{$\begin{array}{c}\text { REF } \\
\text { CODE }\end{array}$} & \multicolumn{4}{|c|}{ Characteristics } \\
\hline & & & ARFL (m) & Wingspan (m) & OMGWS (m) & Length (m) \\
\hline 1 & A 320 & $3 \mathrm{C}$ & 2090 & 34,1 & 8,70 & 37,6 \\
\hline 2 & ATR 725 & $3 \mathrm{C}$ & 1220 & 27,0 & 4,78 & 27,2 \\
\hline 3 & В $737-200$ & $4 C$ & 1990 & 28,4 & 5,91 & 30,53 \\
\hline 4 & В $737-300$ & $4 \mathrm{C}$ & 1940 & 28,9 & 5,91 & 33,4 \\
\hline 5 & B $737-500$ & $4 C$ & 1830 & 28,9 & 6,40 & 31 \\
\hline 6 & B $737-800$ & $4 \mathrm{C}$ & 2256 & 34,3 & 6.40 & 39,5 \\
\hline 7 & В $737-900$ & $4 \mathrm{C}$ & 2240 & 34,3 & 6,40 & 42,1 \\
\hline 8 & В 737-900 ER & $4 \mathrm{C}$ & 2240 & 34,3 & 6,40 & 42,1 \\
\hline 9 & CRJ-1000 ER & $4 \mathrm{C}$ & 2079 & 26,2 & 5,25 & 39,1 \\
\hline
\end{tabular}

\subsubsection{Runway}

The analysis of the runway is performed based on two types of aircraft. First, the operating aircraft which has the longest airplane reference field length (ARFL), namely B $737-800$ (2256 m). Second, B 747 - 300, the largest aircraft operated in 2026 with ARFL of $3320 \mathrm{~m}$ (future planning). Based on the existing local conditions, it was identified that the calculation result of corrected Runway Length, was as follow:

elevation correction factor $(\mathrm{Fe})=1,0091$;

temperature correction factor $(\mathrm{Ft})=1,153$;

slope correction factor $(\mathrm{Fs})=1,004$.

1. For B 737-800, it was calculated that Lro $=$

Lro $=$ ARFL $\times$ Fe $\times$ Ft $\times$ Fs

$=2256 \times 1,009 \times 1,153 \times 1,004$

$=2636 \mathrm{~m}$

2.For B 747-300, it was calculated that Lro $=$

Lro $=$ ARFL $x$ Fe $x$ Ft $x$ Fs

$=3320 \times 1,009 \times 1,153 \times 1,004=3878 \mathrm{~m}$
The existing runway of Hang Nadim Airport is $4025 \mathrm{~m}(>3878 \mathrm{~m})$. Therefore, the existing runway is no need to be expanded until 2026.

The aim of this aerodrome reference code (ARC) is as a simple method for interrelating the number of aerodrome specifications to its requirement facilities suitable to accommodate the operated airplanes. The ARC contains 3 main elements such as; code number, code element 1 (the airplane performance characteristics (ARFL), and code element 2 (dimensions of wingspan and outer main wheel gear).

Table 4. Aerodrome Reference Code (ARC)

\begin{tabular}{|c|c|c|c|c|}
\hline \multicolumn{2}{|r|}{ Code element 1} & \multicolumn{3}{|c|}{ Code element 2} \\
\hline $\begin{array}{l}\text { Code } \\
\text { number } \\
\text { (1) }\end{array}$ & $\begin{array}{l}\text { Aeroplane reference } \\
\text { field length } \\
\text { (2) }\end{array}$ & $\begin{array}{l}\text { Code } \\
\text { letter } \\
\text { (3) }\end{array}$ & $\begin{array}{l}\text { Wing span } \\
\text { (4) }\end{array}$ & $\begin{array}{l}\text { Outer main gear } \\
\text { wheel span } \\
\text { (5) }\end{array}$ \\
\hline 1 & Less than $800 \mathrm{~m}$ & A & $\begin{array}{l}\text { Up to but not } \\
\text { including } 15 \mathrm{~m}\end{array}$ & $\begin{array}{l}\text { Up to but not } \\
\text { including } 4.5 \mathrm{~m}\end{array}$ \\
\hline 2 & $\begin{array}{l}800 \mathrm{~m} \text { up to but not } \\
\text { including } 1200 \mathrm{~m}\end{array}$ & B & $\begin{array}{l}15 \mathrm{~m} \text { up to but not } \\
\text { including } 24 \mathrm{~m}\end{array}$ & $\begin{array}{l}4.5 \mathrm{~m} \text { up to but not } \\
\text { including } 6 \mathrm{~m}\end{array}$ \\
\hline 3 & $\begin{array}{l}1200 \mathrm{~m} \text { up to but not } \\
\text { including } 1800 \mathrm{~m}\end{array}$ & $\mathrm{c}$ & $\begin{array}{l}24 \mathrm{~m} \text { up to but not } \\
\text { including } 36 \mathrm{~m}\end{array}$ & $\begin{array}{l}6 \mathrm{~m} \text { up to but not } \\
\text { including } 9 \mathrm{~m}\end{array}$ \\
\hline \multirow[t]{3}{*}{4} & $1800 \mathrm{~m}$ and over & D & $\begin{array}{l}36 \mathrm{~m} \text { up to but not } \\
\text { including } 52 \mathrm{~m}\end{array}$ & $\begin{array}{l}9 \mathrm{~m} \text { up to but not } \\
\text { including } 14 \mathrm{~m}\end{array}$ \\
\hline & & E & $\begin{array}{l}52 \mathrm{~m} \text { up to but not } \\
\text { including } 65 \mathrm{~m}\end{array}$ & $\begin{array}{l}9 \mathrm{~m} \text { up to but not } \\
\text { including } 14 \mathrm{~m}\end{array}$ \\
\hline & & F & $\begin{array}{l}65 \mathrm{~m} \text { up to but not } \\
\text { including } 80 \mathrm{~m}\end{array}$ & $\begin{array}{l}14 \mathrm{~m} \text { up to but not } \\
\text { including } 16 \mathrm{~m}\end{array}$ \\
\hline
\end{tabular}

Based on table 4 the type of this Hang Nadim Airport runway is $4 \mathrm{E}$ as the runway length $>1800$ $\mathrm{m}$ and $\mathrm{B} 747-300$, wingspan $=59,6 \mathrm{~m}$ (wingspan $<65)$, and length $=56,30 \mathrm{~m}$

\subsubsection{Taxiway}

Based on Annex 14 2013, the evaluation of the existing taxiway is no need to be expanded until 2026. The existing taxiways are 2 exit taxiways with dimensions of $150 \mathrm{~m} \times 23 \mathrm{~m}$ and 2 rapid exit taxiways with dimensions of $300 \mathrm{~m} \times 23 \mathrm{~m}$. The following table was the taxiway's dimensions as on Table 5 below.

Table 5. Dimensions of taxiway

\begin{tabular}{ccc}
\hline Code & Classification & Width of taxiway $(\mathrm{m})$ \\
\hline A & I & 7,5 \\
B & II & 10,5 \\
C & III & $15^{\mathrm{a}}$ \\
& & $18^{\mathrm{b}}$ \\
D & IV & $18^{\mathrm{c}}$ \\
& & $23^{\mathrm{d}}$ \\
\hline E & VI & 23 \\
\hline F & VI & 25 \\
\hline
\end{tabular}


As the taxiways and runway are no need to be expanded, the current condition of these landing movements is no need to be re-designed up to 2026.

\subsubsection{Apron}

The existing Hang Nadim Airport has an apron area with the capacities for accommodating 13 aircrafts such as B747-SP, B737-900, dan F27. In fact, in 2016 (when this research was conducted), the apron has to be able to accommodate 19 aircraft. The calculation of existing apron requirements in 2016 was shown in the table below:

Table 6. Calculation of existing apron requirements in 2016

\begin{tabular}{|c|c|}
\hline $\begin{array}{l}\text { a. Clearances } \\
\text { b. The distances between parallel aircraft } \\
\text { at apron w. other buildings } \\
\text { c. The clearances between parked aircraft } \\
\text { with aircraft in the taxi lane and other } \\
\text { obstructions } \\
\text { d. Distances between aircraft to the } \\
\text { terminal building }\end{array}$ & $\begin{array}{l}10 \mathrm{~m} \\
9 \mathrm{~m}\end{array}$ \\
\hline \multicolumn{2}{|c|}{$\begin{array}{l}\text { Category I (B747-SP) wingspan }=59,6 \mathrm{~m} \text { and } \\
\text { length }=56,30 \mathrm{~m}\end{array}$} \\
\hline $\begin{array}{l}\text { Length of the apron (wingspan }+a) \\
\text { Width (aircraft length }+d+\text { wingspan }+c)\end{array}$ & $\begin{array}{r}74,6 \mathrm{~m} \\
134,90 \mathrm{~m}\end{array}$ \\
\hline \multicolumn{2}{|c|}{$\begin{array}{l}\text { Category II (B737-900) wingspan }=34,3 \mathrm{~m} \text { and } \\
\text { length }=42,1 \mathrm{~m}\end{array}$} \\
\hline $\begin{array}{l}\text { Length of the apron (wingspan }+ \text { a ) } \\
\text { Width (aircraft length }+d+\text { wingspan }+c)\end{array}$ & $\begin{array}{r}38,8 \mathrm{~m} \\
92,90 \mathrm{~m}\end{array}$ \\
\hline \multicolumn{2}{|c|}{$\begin{array}{l}\text { Category III (F27) wingspan }=29,00 \mathrm{~m} \text { and length } \\
=25,1 \mathrm{~m}\end{array}$} \\
\hline $\begin{array}{l}\text { Length of the apron (wingspan }+a \text { ) } \\
\text { Width (aircraft length }+d+\text { wingspan }+c)\end{array}$ & $\begin{array}{r}33,50 \mathrm{~m} \\
70,6 \mathrm{~m}\end{array}$ \\
\hline $\begin{array}{lll}\begin{array}{l}\text { Existing } \\
\text { aircraft) }\end{array} & \text { Apron } & \text { Requirements } \\
\end{array}$ & \\
\hline 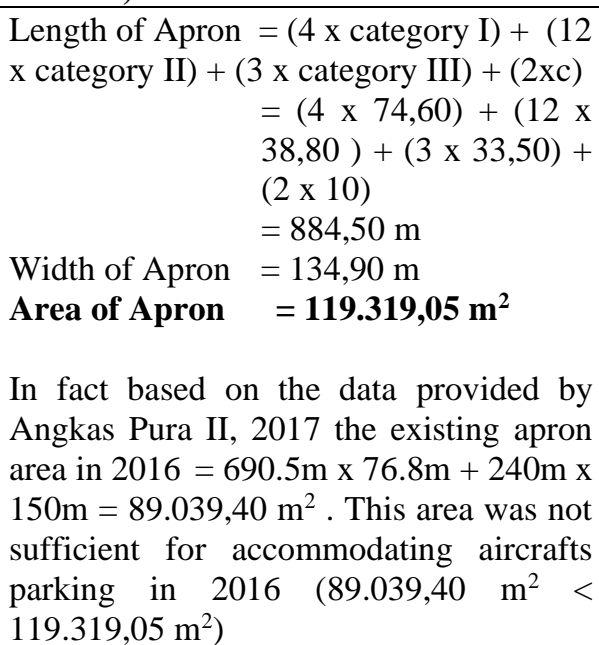 & \\
\hline
\end{tabular}

According to the aircraft's peak hours projection in 2026, the apron is designed to accommodate 31 aircraft (table 2). Then, it was calculated that the future apron in 2026 would require the extension areas as follow (Table 6):

Table 7. Calculation of apron requirements in 2026

a. Clearances $4.5 \mathrm{~m}$

b. The distances between parallel aircraft $10 \mathrm{~m}$ in the apron with other buildings

c. The clearances between parked aircraft with aircraft in the taxi lane and other $10 \mathrm{~m}$ obstructions

d. Distances between aircraft to the terminal building $10 \mathrm{~m}$

Category I (B737-300) wingspan $=59,6 \mathrm{~m}$ and length $=70,7 \mathrm{~m}$

Length of the apron (wingspan $+\mathrm{a}$ ) 74,60m

Width (aircraft length $+\mathrm{d}+$ wingspan $+\mathrm{c}$ ) 149,30m

Category II (B737-900) wingspan $=34,3 \mathrm{~m}$ and length

\section{$=42,1 \mathrm{~m}$}

Length of the apron (wingspan $+\mathrm{a}$ ) 38,80m

Width (aircraft length $+\mathrm{d}+$ wingspan $+\mathrm{c}$ ) $\quad 92,90 \mathrm{~m}$

Category III (F27) wingspan $=29,00 \mathrm{~m}$ and length

$=25,1 \mathrm{~m}$

Length of the apron (wingspan $+\mathrm{a}$ ) 33,50m

Width (aircraft length $+\mathrm{d}+$ wingspan $+\mathrm{c}$ ) $\quad 70,60 \mathrm{~m}$

Existing Apron Requirements (31

aircraft)

Length of Apron $=(11 \times$ category $\mathrm{I})+(16$

$\mathrm{x}$ category II $)+(4 \mathrm{x}$ category III $)+(2 \mathrm{x} \mathrm{c})$

$=(11 \times 74,60)+(16 \times$

$38,80)+(4 \times 33,50)+(2$

$\mathrm{x} 10)$

$=1595.40 \mathrm{~m}$

Width of Apron $=134,90 \mathrm{~m}$

Dimensions of planned apron $=1600 \mathrm{~m} \mathrm{x}$

$150 \mathrm{~m}=240.000,00 \mathrm{~m}^{2}$

Hence it was calculated that there would be constructed additional up to 240 thousand $\mathrm{m} 2$ of the apron area in 2026 from 89 thousand $\mathrm{m} 2$ in 2016. The magnitude scale of this development $=270 \%$.

\section{Conclusion}

The existing Hang Nadim Airport runway 2016 was $4025 \mathrm{~m}$. This runway is able to accommodate (wide-body aircraft of B747-300) in the new future demand 2026. The existing taxiways (2 Exit Taxiways of $150 \mathrm{~m} \times 23 \mathrm{~m}$ and 2 Rapid Exit Taxiways of $300 \mathrm{~m} \times 23 \mathrm{~m}$ ) were also considered sufficient to accommodate the future demand in 2026. The existing apron $(690,5 \mathrm{~m} \times 76,8 \mathrm{~m}$ and 240 $\mathrm{m} \times 150 \mathrm{~m}$ ) has a capacity of 13 aircraft would in a 
need to be expanded up to $1600 \mathrm{~m}$ x $150 \mathrm{~m}$ (in order to facilitate 31 aircraft (11 units B747- $300+16$ units B737-900 + 4 units F27).

\section{Acknowledgement}

The authors gratefully acknowledge this research is supported by The Business Board of Hang Nadim Airport.

\section{References}

[1] [1] Gito Sugiyanto, Purwanto Bekti Santosa, Aris Wibowo, and Mina Yumei Santi, 2017, Airport Classification Based On Freight Ratio And Federal Aviation Administration (Case Study In Indonesia), ARPN Journal of Engineering and Applied Sciences, Vol. 12, No. 2, January 2017, ISSN 1819-6608, (C)2006-2017, Asian Research Publishing Network (ARPN). 579-587.

[2] PT. Angkasa Pura II, 2017, Lose Reports of Hang Nadim International Airport Traffic Movement 20072018, PT. AP II, Jakarta.

[3] Özdemir, Mustafa., Çetek, Cem., Usanmaz., Öznur. (2018). Airside Capacity Analysis And Evaluation Of İstanbul Atatürk Airport Using Fast-Time Simulations. Anadolu Univ. J. of Sci. and Technology A - Appl. Sci. and Eng Vol 19(1). 153164.

[4] Laplacea, Isabelle., Latgé-Roucolleb, Chantal. (2016). Deregulation of the ASEAN air Transport Market: Measure of Impacts of Airport Activities on Local Economies. Transportation Research Procedia 14, 3721-3730.

[5] Robert, H., Francis, M., William, S., \& Seth, Y. (2010). Planning and Design of Airports, Fifth Edition. (Fifth, Ed.) (Fifth). New York: Mc Graw Hill.
[6] KM 44, (2002). Tatanan Kebandarudaraan Nasional. Minitry of Transpotation, Indonesia, 1-11.

[7] ICAO, 2013, Aerodrome Design and Operations, International Civil Aviation Organization (ICAO), Annex 14, Vol. I, Six Edition, 1-11.

[8] Majid, R, Ahmad Mir, Shakeel (2018). Advances in Statistical Forecasting Methods: An Overview. Procedia Computer Science 135. 671-677.

[9] Armstrong, J.S. (2001). Principles of Forecasting: A Handbook for Researchers and Practitioners. Springer-233 Spring Street.

[10]Diana Permai, Syarifah, Tanty, Heruna (2018). Linear regression model using bayesian approach for energy performance of residential building. Procedia Computer Science 135. 671-677.

[11] Uyanik, Kaya., Guler, Nese. (2013). A Study on Multiple Linear Regression. Procedia - Social and Behavioral Sciences Volume 106. 234-240

[12] Gomes de Barros, Alexandre., Chandana Wirasinghe, Sumedha. (1997) Aircraft Characteristicsrelated To Airport Planning. Air Transport Research Groupof the WCTR Society.

[13] Ugnenko, Evgeniya., Perova, Elena., Voronova, Yelizaveta., Viselga, Gintas. (2017). Improvement of the Mathematical Model for Determining the Length of The Runway at the Stage of Aircraft Landing. Procedia Engineering 187. 733-741.

[14]T. Wells, Alexander., B. Young, Seth. (2011). Airport Planning and Management, Sixth Edition. Library of Congress Cataloging-in-Publication Data.

[15] Hamzah, Suharman., Adji Adisasmita , Sakti. (2015). Aircraft parking stands: proposed model for Indonesian airports. Procedia Environmental Sciences $28.324-329$

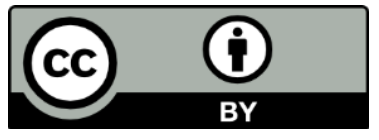

This is an open-access article distributed under the terms of the Creative Commons Attribution 4.0 International License (CC-BY). 